\title{
Cost-Effectiveness Analysis of Gemtuzumab Ozogamicin for First-Line Treatment of Patients with Cd-33 Positive Acute Myeloid Leukaemia in Spain [Corrigendum]
}

\author{
Mareque M, Montesinos P, Font P, et al. Clinicoecon The authors apologize for this error. \\ Outcomes Res. 2021;13:263-277.
}

Page 271, Results, Base Case, second line from the bottom, the text " $€ 15,134$ " should read " $€ 151,434$ ".

\section{Publish your work in this journal}

ClinicoEconomics and Outcomes Research is an international, peerreviewed open-access journal focusing on Health Technology Assessment, Pharmacoeconomics and Outcomes Research in the areas of diagnosis, medical devices, and clinical, surgical and pharmacological intervention. The economic impact of health policy and health systems organization also constitute important areas of coverage. The manuscript management system is completely online and includes a very quick and fair peer-review system, which is all easy to use. Visit http://www.dovepress.com/testimonials.php to read real quotes from published authors. 